\title{
UNTILIZATION OF Moringa oleifera LEAF EXTRACT ON DECREASING INFESTATION OF Argulus japonicus IN GOLDFISH (Carassius auratus)
}

Febri Setyawati $^{1} \cdot$ Kismiyati $^{1} \cdot$ Sri Subekti $^{1}$

Ringkasan Goldfish (Carassius auratus) is one of the fishes that can be infected by parasites. Commonly, this fish is often attacked by Argulus japonicus ectoparasites. Control of infestation in A. japonicus can be done by utilizing one of the natural ingredients, Moringa oleifera leaf extract, which contains of alkaloids, tannins, saponins and flavonoids. This study aims to determine the effect of $M$. oleifera leaf extract in reducing the infestation of $A$. japonicus and the optimal concentration of M. oleifera leaf extract in reducing the infestation of A. japonicus in goldfish (C. auratus). This study used a completely randomized design (CRD) with treatments namely control, $600 \mathrm{ppm}$, 700 ppm, 800 ppm and 900 ppm with four times of replication. The main parameter is the percentage decrease in infestation of A. japonicus. The results of the research data were analyzed by using ANOVA and followed with the Ducan Multiple Range Test. The results showed that Moring a leaf extract could reduce the infestation of A. japoni-

$\left.{ }^{1}\right)$ Program Studi Akuakultur, Fakultas Perikanan dan Kelautan, Universitas Airlangga, Jl. Dharmahusada Permai No. 330 Surabaya 60115 Indonesia E-mail: febrisetyawati02@gmail.com cus. The optimal concentration of Moringa leaf extract in reducing the infestation of A. japonicus was obtained from a concentration of $700 \mathrm{ppm}$.

Keywords Moringa oleifera leaf extract, Carassius auratus, Argulus japonicus

Received : 15 September 2019

Accepted : 20 Oktober 2019

\section{PENDAHULUAN}

Ikan maskoki merupakan salah satu ikan yang mudah terinfeksi parasit (Pongkowulao, 2012). Parasit pada ikan maskoki yang sering menyerang adalah ektoparasit A. japonicus. Prevalensi A. japonicus tahun 2014 di pasar ikan hias Surabaya yaitu $73,4 \%$ di pasar hias Patua dan $16,7 \%$ di pasar hias Gunung sari (Hermawan, 2014).

Pengendalian infestasi A. japonicus dengan menggunakan bahan alami seperti pada penelitian (Kalsasin, 2014), menggunakan perasaan biji papaya dapat menurunkan infestasi $A$. japonicus pada konsentrasi optimal 50 ppt sebesar $45 \%$. Penurunan infestasi A. japonicus dapat 
dilakukan dengan memanfaatkan bahan alami lainnya yaitu ekstrak daun kelor (M. oleifera). Ekstrak daun kelor (M. oleifera) memiliki kandungan $0.42 \%$ alkaloid, $8.22 \%$ tanin, dan $1.75 \%$ saponin (Ojiako, 2014). Kandungan ekstrak daun M. oleifera dapat menyebabkan A. japonicus lepas dari inang sehingga dapat menyebabkan kematian.

Tujuan Penelitian adalah untuk mengetahui pengaruh dan konsentrasi optimal ekstrak daun kelor (M. oleifera) dalam menurunkan infestasi A. japonicus pada ikan maskoki (C. auratus).

\section{MATERI DAN METODE}

Alat yang digunakan dalam penelitian adalah satu akuarium pemeliharaan dengan ukuran 48x30x28 $\mathrm{cm}^{3}, 20$ akuarium untuk perlakuan dengan ukuran $15 \times 15 \times 30 \mathrm{~cm}^{3}$, selang, aerator, batu aerasi, timbangan digital, kertas saring, beaker gelas $500 \mathrm{~mL}$, DO meter, kertas $\mathrm{pH}$, aluminium foil, termometer, nampan, penggaris, blender, rotary vacuum evaporator. Bahan yang digunakan dalam penelitian yaitu 40 ekor ikan maskoki dengan ukuran $5-10 \mathrm{~cm}, A$. japonicus sebanyak 240 ekor, 400 gram daun kelor yang sudah dikeringkan, etanol 96\%, air PDAM yang telah diendapkan dan pellet.

Daun kelor berwarna hijau gelap yang masih segar dipisahkan dari tangkainya sebanyak 2 kilogram kemudian dikeringkan pada suhu ruangan $30-35^{\circ} \mathrm{C}$ selama 24 jam (Oluduro, 2012). Daun kelor dihaluskan dengan blender hingga menjadi serbuk. Serbuk daun kelor dilarutkan dengan etanol 96\% (Kasolo et al., 2011), sampai semua serbuk terendam selama $3 \times 24$ jam pada suhu $30^{\circ} \mathrm{C}$ dan disaring dengan kertas saring. Hasil saringan selanjutnya dievaporasi menggunakan rotary vacuum evaporator selama 1 jam 30 menit pada suhu $50-55^{\circ} \mathrm{C}$ (Wulandari et al., 2018). Hasil ekstrak dimasukkan ke dalam petridish ditunggu hingga dingin lalu ditutup menggunakan aluminium foil selama 7 hari.

Infestasi buatan A. japonicus dilakukan terlebih dahulu yaitu infestasi tiga ekor A. japonicus pada masing-masing ikan maskoki ke dalam akuarium tunggu hingga $A$. japonicus menempel pada ikan mas koki. Tingkat infestasi ringan ditentukan 1-5 A. japonicus yang menempel pada setiap ekor ikan (Kismiyati, 2009).

Sebanyak dua ekor ikan maskoki yang telah terinfeksi A. japonicus, dimasukan ke dalam masing-masing akuarium sesuai dengan perlakuan. Pengamatan pada ikan maskoki dilakukan selama 69 jam.

Analisis data dalam penelitian ini menggunakan analisis keragaman atau ANOVA. Apabila hasil analisis sidik ragam menunjukkan pengaruh yang berbeda nyata atau berbeda sangat nyata, maka untuk perbandingan nilai dilakukan dengan uji jarak berganda Duncan untuk mengetahui perbedaan antara perlakuan satu dengan perlakuan yang lain.

\section{HASIL DAN PEMBAHASAN}

Konsentrasi ekstrak daun kelor pada penelitian berdasarkan pada penelitian pendahuluan yang telah dilakukan. Hasil penelitian menunjukkan bahwa perlakuan A (Kontrol) dan B (600 ppm) tidak berbeda nyata, hal ini disebabkan 
Tabel 1 Rata-rata persentase penurunan infestasi $A$. japonicus

\begin{tabular}{cc}
\hline Perlakuan & Rata-rata $(\%) \pm$ SD \\
\hline A (Kontrol) & $37.47^{a} \pm 43.84$ \\
B $(600 \mathrm{ppm})$ & $37.47^{a} \pm 8.35$ \\
C $(700 \mathrm{ppm})$ & $83.30^{b} \pm 13.63$ \\
D $(800 \mathrm{ppm})$ & $70.80^{a b} \pm 15.94$ \\
E $(900 \mathrm{ppm})$ & $79.15^{b} \pm 29.66$ \\
\hline
\end{tabular}

lamanya proses perendaman ekstrak daun kelor yaitu 69 jam. Perlakuan A (Kontrol) mengalami kematian ikan sebanyak tiga ekor sehingga adanya penurunan infestasi Argulus japonicus, hal ini dikarenakan tanpa adanya penambahan ekstrak daun kelor sehingga A. japonicus mengambil nutrisi pada ikan. Perlakuan C (700 ppm), D (800 ppm) dan E (900 ppm) juga tidak berbeda nyata, hal ini disebabkan karena adanya kematian ikan pada perlakuan D sebanyak empat ekor dan perlakuan E sebanyak enam ekor ikan dari total delapan ekor jumlah ikan dalam satu perlakuan. Perbedaan perlakuan yang nyata terdapat pada perlakuan A, B dengan perlakuan C, D dan E (Tabel 1). Berdasarkan uji ANOVA, hasil penelitian menunjukkan adanya pengaruh pemberian ekstrak daun kelor terhadap penurunan infestasi A. japonicus pada ikan Maskoki, kemudian dilanjutkan dengan uji jarak berganda Duncan menunjukkan adanya perbedaan notasi pada pada beberapa perlakuan. Hasil konsentrasi terbaik pada perlakuan C (700 ppm) yaitu persentase rata-rata penurunan infestasi A. japonicus adalah $83.3 \%$.

Pemberian ekstrak daun kelor pada ikan Maskoki yang terserang A. japonicus dapat menyebabkan terlepasnya parasit tersebut dari inang. Hal ini disebabkan ekstrak daun kelor memiliki kandungan alkaloid, tannin, saponin dan flavonoid (Rohyani et al., 2015). Senyawa saponin memiliki mekanisme ker- ja yaitu menghambat pembentukan senyawa kompleks membran sel melalui ikatan hidrogen, sehingga dapat menghancurkan sifat permeabilitas membran sel hingga menimbulkan kematian sel (Juliantina et al., 2009). Senyawa flavonoid dapat merusak membran sel dengan cara mendenaturasi protein pada membran sel,sehingga membran sel terganggu permeabilitasnya dan menyebabkan kebocoran isi sel (Rohyani et al., 2015). Senyawa tannin yang bersifat mengikat protein sehingga dapat menggangu proses penyerapan protein, tannin juga dapat mengerutkan membran sel sehingga menggangu permeabilitas sel (Ajizah, 2018). Senyawa alkaloid bersifat menyerang sistem syaraf sehingga menimbulkan gejala kelumpuhan dan mengakibatkan kematian (Juliantina et al., 2009).

Hasil pengamatan kualitas air sebelum dan sesudah perlakuan mengalami perubahan. Perubahan kualitas air masih dikatakan baik, sebab selisih perbedaan masih dalam kisaran parameter kualitas air yang baik untuk ikan maskoki. Parameter yang diukur yaitu derajat keasaman $(\mathrm{pH})$ dengan menggunakan $\mathrm{pH}$ pen, sedangkan oksigen terlarut (DO) dan suhu dengan menggunakan oksigen terlarut (DO) digital. Hasil perubahan parameter $\mathrm{pH}$ setelah perlakuan menunjukkan adanya kenaikan. Perubahan pada kenaikan $\mathrm{pH}$ tidak berpengaruh karena ikan maskoki dapat hidup dengan kisaran $\mathrm{pH}$ 6-7 (Fitriana et al., 2016). Hasil pengamatan oksigen terlarut (DO) mengalami penurunan pada setiap perlakuan. Perubahan oksigen terlarut (DO) masih dikatakan baik sebab ikan maskoki hidup dengan kisaran DO 4-7 mg/L (Premalatha and Lipton, 2007). Hasil pengamatan suhu 
mengalami penurunan. Hasil pengamatan suhu setelah perlakuan masih menunjukkan kisaran suhu yang baik untuk pertumbuhan ikan maskoki yaitu berkisar antara $23-29^{\circ} \mathrm{C}$ (Premalatha and Lipton, 2007). Data rata-rata kualitas air pada penelitian ini disajikan pada Tabel 2.

\section{SIMPULAN}

Berdasarkan hasil penelitian, ekstrak daun kelor (M. oleifera) terbukti dapat digunakan untuk menurunkan infestasi $A$. japonicus pada ikan Maskoki (C. aura$t u s)$. Konsentrasi optimal ekstrak daun kelor yang dapat diberikan untuk menurunkan infestasi pada ikan Maskoki selama 69 jam adalah 700 ppm dengan rata-rata persentase penurunan sebesar $83.30 \%$.

\section{Pustaka}

Ajizah, A. (2018). Sensitivitas salmonella typhimurium terhadap ekstrak daun psidium guajava 1 . Bioscientiae, 1(1).

Fitriana, N., Subamia, I. W., and Wahyudi, S. (2016). Pertumbuhan dan performansi warna ikan mas koki (carassius sp.) melalui pengayaan pakan dengan kepala udang.

Hermawan, T. (2014). Prevalensi dan intensitas argulus japonicus pada ikan maskoki (carassius auratus) yang dipasarkan di pasar ikan hias surabaya. Skripsi. Budidaya Perairan. Fakultas Perikanan dan Kelautan. Universitas Airlangga. Surabaya. hal, 50.

Juliantina, F., Citra, D. A., Nirwani, B., Nurmasitoh, T., and Bowo, E. T.
(2009). Manfaat sirih merah (piper crocatum) sebagai agen antibakterial terhadap bakteri gram positif dan gram negatif. Jurnal kedokteran dan kesehatan Indonesia, 1(1):12-20.

Kalsasin, D. D. (2014). Pemanfaatan perasan biji pepaya (carica papaya) untuk mencegah infestasi argulus pada ikan maskoki (carassius auratus). PhD thesis, UNIVERSITAS AIRLANGGA.

Kasolo, J., Bimenya, G., Ojok, L., and Ogwal-Okeng, J. (2011). Phytochemicals and acute toxicity of moringa oleifera roots in mice. Journal of Pharmacognosy and Phytotherapy, 3(3):38-42.

Kismiyati (2009). Ektoparasit Argulus japonicus (Crustacea: Argulodae) pada Ikan Maskoki Carassius auratus (Crypriniformes: Cyprinidae) dan Upaya Pengendalian dengan Ikan Sumatera Puntius tetrazone (Cyprinisformes: Cyprinidae). $\mathrm{PhD}$ thesis, Program Pascasarjana. Universitas Airlangga.

Ojiako, E. (2014). Phytochemical analysis and antimicrobial screening of moringa oleifera leaves extract. International Journal of Engineering Science, 3:32-35.

Pongkowulao, D. F. (2012). Pengaruh Lama Infestasi Ektoparasit Argulus sp. pada Pertumbuhan Ikan Maskoki (Carassius auratus). PhD thesis, UNIVERSITAS AIRLANGGA.

Premalatha, Y. and Lipton, A. (2007). Water quality management in gold fish (carassius auratus) rearing tanks using different filter materials. Indian Hydrobiology, 10(2):301-306.

Rohyani, I. C., Aryanti, E., and Suripto (2015). Kandungan fitokimia beberapa jenis tumbuhan lokal yang sering dimanfaatkan sebagai bahan ba- 
Tabel 2 Data kualitas air sebelum dan sesudah perlakuan

\begin{tabular}{ccccccc}
\hline \multirow{2}{*}{ Perlakuan $(\mathrm{ppm})$} & \multicolumn{3}{c}{ Sebelum Perlakuan } & \multicolumn{3}{c}{ Sesudah Perlakuan } \\
\cline { 2 - 7 } & $\mathrm{pH}$ & $\mathrm{DO}(\mathrm{mg} / \mathrm{L})$ & Suhu $\left({ }^{\circ} \mathrm{C}\right)$ & $\mathrm{pH}$ & $\mathrm{DO}(\mathrm{mg} / \mathrm{L})$ & $\mathrm{S}$ Suhu $\left({ }^{\circ} \mathrm{C}\right)$ \\
\hline A (Kontrol) & 7 & 4.46 & 28.5 & 7.2 & 4.34 & 27.1 \\
B (600) & 6.9 & 4.36 & 28.8 & 7.2 & 4.34 & 27 \\
C (700) & 6.9 & 4.43 & 28.8 & 7.3 & 4.32 & 27 \\
D (800) & 6.9 & 4.36 & 28.9 & 7.3 & 4.28 & 27 \\
E (900) & 6.8 & 4.49 & 28.8 & 7.3 & 4.39 & 26.9 \\
\hline
\end{tabular}

ku obat di pulau lombok. In Pros Sem Nas Masy Biodiv Indon, volume 1, pages 288-391.

Wulandari, M. A., Solikhah, L. I., and Wulan, S. N. (2018). Uji toksisitas subkronis serbuk, ekstrak air, dan ekstrak pekat suplemen kalsium daun kelor (moringa oleifera lam.) pada fungsi hepar dan ginjal tikus wistar (rattus norvegicus). Jurnal Pangan dan Agroindustri, 5(4). 
